\title{
Sea Defense Strategy of Anti-Submarine on We Island
}

\author{
Agus Damar Jaya $^{1^{*}} \quad$ Suhirwan $^{2} \quad$ Lukman YudhoPrakoso $^{2} \quad$ Purwanto $^{2}$ \\ Dohar Sianturi ${ }^{2} \quad$ Resmanto Widodo Putro ${ }^{2}$ \\ 1. Students, Study Program of Sea Defense Strategy, Defense Strategy Faculty, University of Defense of \\ Indonesia, Bogor, Indonesia \\ 2.Lecturer, Study Program of Sea Defense Strategy, Defense Strategy Faculty, University of Defense of \\ Indonesia, Bogor, Indonesia
}

\begin{abstract}
We island belonging to Indonesia at the lowest position in the west end which is the basis of the outer defenses of the earliest in the face of possible threats from the outside, especially the threat of attack from the sea. Marine threat which could give psychological pressure on closers strategic funnels and its presence is difficult to detect and is capable of operating for a long time is the threat of submarines. This study aimed to describe and analyze the anti-submarine naval defenses on the island We if linked to possible threats arising submarine in the area that can be used as input by the leadership in making decisions in the future. The study was conducted by the method of the subject matter of literature and anti-submarine warfare. It is concluded that anti-submarine defense pattern idyllic island We by utilizing all the facilities and potential to face any possibility of a threat submarine opponents and use their combat functions by the opponent effectively in the waters of the We island
\end{abstract}

Keywords: sea defense, submarine, We island

DOI: $10.7176 / \mathrm{IAGS} / 81-03$

Publication date:March $31^{\text {st }} 2020$

\section{Introduction}

Geopolitics the views interpret the Indonesian nation in the homeland of Indonesia as a unit that includes the entire region and all the forces of the nation which includes ideological, political, economic, social, cultural and defense security of the country is Archipelago. Based Politics and National Strategy and by being aware of the possibility of threat from within and outside the country, the pattern of the National Security and Defense (Hankamnas) is active in the field of defense defensive and preventive active in the field of security. Both of the above is intended to safeguard national development, organize and develop the ability Hankamnas capable of tackling all forms of threats and manifestations, wherever it comes from. We island, which is a region of Indonesia at the lowest position in the west end is a base outer defenses of the earliest in the face of possible threats of attacks from outside, in particular the threat that comes from the sea. In addition We island also have a strategic value in terms of geographical location, resources, marine biological and non biological and other significant potential both as sources of strategic commodities in the international arena.

Marine threat that can provide psychological pressure on closers funnels positioned where its presence is difficult to detect and capable of operating in a long time is the threat of submarines. Advantages and limitations in the submarine can make the factors to be considered in carrying out the action and anti-submarine defense pattern in an area that nature allows for the operation of the submarine, like in We island. Anti-Submarine in a certain area that is geographically and hydrographic is possible for the operation of submarines, aims to prevent the enemy from using function effectively combat submarine in the region or the area. As for the defense adjusted pattern with pattern submarine operations in the waters around the coastline and inland waters (Inshore Waters). The purpose of this paper is to give an overview of the Sea Defense Anti-submarine on We island, linked to possibility submarine threats that arise in the area with the aim that can be used as input in the decision making in the future. The method used is the method of approach to literature and the subject matter of AntiSubmarine Warfare.

\section{Discussion}

\subsection{Geographic Location We Island.}

We island is an island at the far end next to the Northwest Indonesia, geographic conditions that directly deal with the Indian Ocean and as a mouthpiece of the entry door and out of shipping lanes to and from the waterway. The waters around We island are grooves strategic commercial shipping (Shipping Channel Malacca) with the Strait of Bengal from the Indian Ocean to the Strait of Malacca. The waters around the We island had a sea depth deep enough and very suitable for the operation of the submarine.

\section{$2.2 \quad$ Estimated Threats}

The threat of a foreign submarine that might be encountered in the waters of the island and surrounding areas We expected to come from countries that are in the region of West Asia and Southeast Asia, or may also come from 
a superpower with interests in the Indian Ocean which have military bases in the region the. These countries include:

a. Indian Navy.

Base Indian Navy submarine closest to We Island are Naval in Andaman and Nicobar Islands within $\pm 200 \mathrm{NM}$ from We Island. The submarine owned by the Indian Navy, among others:

- class submarines 209/1500 (SS) 6 units

- Kilo class submarines / Amur (SS) 6 units

- Foxtrot class submarines (SS) 4 units

- Indian Navy ever hired a Charlie class nuclear submarine II (SSGN), but has returned to the country of origin (Russia), because of difficulties in terms of cost of operation for 1-2 years. However, the Indian Navy is the only country that has experience in manned nuclear submarine in the South Asian region.

b. Pakistan Navy.

Owned submarine of the Pakistan Navy, among others:

- Agosta class submarines (SS) 4 units.

- Daphne class submarines (SS) 4 units.

c. United States Navy

The US Navy has a military base of Diego Garcia in the Indian Ocean, which is reinforced by several nuclear-powered submarines, such as:

- Los Angeles-class submarine (SSN).

- Sturgeon-class submarine (SSN).

- And some other types of submarines

d. Thai Navy and the Royal Malaysian Navy plans to buy conventional submarines to strengthen its navy, submarines, among others of their choice, such as:

- Malaysia: Class 209/1300 of Turkey.

- Thailand: Agosta and Scorpene Class from France, 206 from Germany.

e. Singapore Navy

Singapore Navy has had four former Swedish submarines, Sjoormen class. The question is, is it possible to be operated to the Indian Ocean.

2.3 Estimated Submarine Assignment opponent in the waters of We Island.

Of the few countries that operate submarines in the Indian Ocean above, is a country that one day will likely be a prospective opponent. Various assignments of several types of submarines on top that allows it to do in the waters of the island and surrounding We are, among others:

a. Anti-Shipping with the goal of marine transportation line termination.

b. Mine deployment.

c. Attacks against ships anchored / docked.

d. Missile strikes against ground targets.

e. Clandestine operations (infiltration infiltrator, Espionage, Passus, Subversive etc.).

f. Surveillance operations (Ops Puldata for amphibians, the movement of warships, the data base/installation surface)

g. As Beacon Navigation or pul Data meteo-Oceanology.

h. Task rescue / Rescue (VIP, etc.).

Of the possibility of submarine assignments mentioned above, it is necessary to anticipate possible threats that will be faced by the Indonesian Navy in We Island as the Navy Base class B and as a place that has a strategic value geographically and economically.

\section{$2.4 \quad$ We Island Strategic Value}

The objects of important / vital that makes the We island have strategic value, among others:

a. General Sabang port and ferry crossing in Balohan, as economic support facilities North Sumatra and North Aceh.

b. Indonesia Navy pier and Maintenance Facilities that can be used as a base aju and support facilities for the aggressor state.

c. Bunker fuel Pertamina, as a liquid supply depot operational support warships and merchant ships.

d. Airbase / airfields that can function as a springboard an air raid.

e. Radar unit as an early detection sensor at Kilometer Zero.

f. Tourism and marine parks in Iboih Rubiah Island.

g. Local fishermen pond which is one of the assets important maritime are on the We island. 


\subsection{Base Defense existing facilities.}

Indonesia Navy base on the We island are the backbone of defense against any possible threats coming from the sea to the island attack, especially against the possible threat of submarine opponent. Amenities bases and all available resources can be deployed as optimally as possible to deal with the threat. As for the base facilities, among others:

a. Sabang naval base the dock berth / supplies the Navy warships (KRI), especially those that have the primary function of the Anti-Submarine (Class Parchim) and having the ability Anti-Submarine (Class Fatahilah / Class Van Speijk). The dock can accommodate 8-10 Navy warships (including submarines) depending on its size.

b. Indonesia Navy Air Base Sabang, which is the base of the elements of the Navy aircraft in Sabang, whether it pesud rotary wing or fixed wing, which can be used for functions Anti-Submarine through aerial surveillance maritime (Maritime surveillance). Air Base can accommodate / receive dozens of Indonesia Navy aircraft of various types.

c. Maintenance Facilities Sabang which is the main facility in terms of maintenance and repair of the Navy warships and aircraft that need improvement.

d. Unit Radar Air Force at Kilometer Zero around Sabang which is a facility early warning of possible threats aircraft-aircraft opponent, be it fighter, bomber, reconnaissance, helicopters and maritime patrol aircraft which is also commonly used in tactical cooperation with elements of submarine opponent , Up to a certain distance radar is capable of detecting surface targets.

e. Visual observer posts. The posts observer visuals placed on the high plains around Pulau We and Pulau Rondo is the postal observer Japanese heritage which is quite useful in the functioning of the observation of surface ships or submarines that are on the surface or in the depths of a periscope or snorkel operating in We island and the waters around of the Rondo island.

f. We island Maritime community as one of the maritime potential that can be used as an extension of the eyes and ears for the Indonesia Navy in implementing the Anti-Submarine defense function in the waters around We island.

\subsection{Defense pattern Anti-Submarine}

Defense pattern Anti-Submarine against operations that may be performed by an opponent submarine in the waters of We island are in the form of attempt / prevention activities against the use of submarines opponent function effectively in the region, while activity / these efforts, among others:

a. Carry out the measurement of the condition of Bathy waters around We island periodically/regularly and hold a survey of each particular season (Bathy Readings) and study the hydrooceanographic environmental conditions surrounding waters We Island.

b. Adding elements of surface or subsurface that have a Bluetooth function or Anti-Submarine as well as conducting periodic patrols Anti-Submarine KAA / routine patrol patterns are adjusted azasinya combat functions:

- $\quad$ Large Area search and Patrol.

Patrol on a wide area where the submarine possibility of operating anti-shipping duties. Carried by several ships Anti-Submarine sonar coverage tailored to the capabilities and sweep width. Coordinated way with helicopters or aircraft maritime patrol.

- $\quad$ Close the search area and Patrol.

Patrol vast areas where the submarine is not the possibility of anti-shipping operation task, the deployment of mines, clandestine operations, reconnaissance and attacks on ships anchored around the dock. Conducted by 1 or 2 Anti-Submarine ship sonar coverage tailored to the capabilities and sweep width. Pattern search (Search Plan) Operation Oak Tree and Pineapple. Could be helped by aircraft maritime patrol and helicopters.

- Lost contact search.

The search for the submarine had been detected beforehand, where appropriate search procedures disappearance. Can be done in concert with Heli Anti-Submarine.

Base Defense operation pattern by Submarine Anti submarine is to make a submarine or the Regional Barrier Insulation Submarine job to destroy each other submarine contact entry in penyekatannya area. To an extent this submarine Area Insulation berganyung of the number of submarines and sonar detection distance capability. Regional defense Insulation We island AntiSubmarine will be held at the Northwest Rondo Island which is the approximate Axis (Axis) submarine threat opponent.

c. Conducting patrols aircraft Anti-Submarine (MPA and Heli) periodic / routine with the addition of the elements of air and implement customized patrol patterns AKS combat functions, such as:

- Large Area MPA search and Patrol (Patrol Anti-Submarine on large areas by aircraft fixed 
wing)

- $\quad$ Close Area MPA search (Anti-Submarine Patrol in areas that are not spacious by aircraft maritime patrol and helicopters. Anti-Submarine).

- This search can be performed with a variety of sensors, including:

i. $\quad$ Visual and ETI (Exhaust Trail Indicator) engines.

ii. Radar search.

iii. MAD (Magnetic Anomaly Detector) engines.

iv. Sonobuoy search.

v. EER (Explosive Echo Range) / Julie engines.

vi. Jezebel search.

vii. ESM search.

viii. Dipping sonar search.

d. Installation implement hydrophones / Transducer underwater fixed / fixed underwater detecting devices (as underwater detection devices monitored from the ground) as SOSUS (Sound Surveillance System). This can increase the ability of detection of the presence of the submarine opponents in our own waters, which is mounted on a funnel corong- closers and end of the island / cape to monitor the entry of submarines (as in Ujung Bau, Rondo Island, Edge Wry, Rubiah Island, Ujung Guhurangsang, Edge Penue Breueh Island, Meuderuroe Edge, Edge Seuke in the Gulf Balohan and tip Baka etc.). So that the submarines are intended to perform the task Clandestine, Anti Shipping and deployment of mines can be detected early and elements of anti-submarine can be immediately deployed to intercept the presence of these submarines.

e. Carry out the installation of nets Anti-submarine (ASW Net Defenses) at the doors of the bay towards the vital or bases such as the entrance to the Bay of Sabang to prevent clandestine operation / infiltration and attacks on ships anchored by submarine, either directly by submarine itself or by special forces opposed to being launched from submarines.

f. Adding placements reviewing posts in the highlands that have a good viewing angle of the waters around We Island. In addition complement observer posts with cannon gun that has a moderate distance / remote for coastal defense operations in anticipation of infiltration, sabotage, reconnaissance and intelligence collect data, meteohidrografi and special rescue submarine.

g. Placing the station-station ESM and DF (Direction Finder) in shore / beach (Shore Electronic Intercept Station) to detect and identify the presence of the submarine threat that an opponent when sending news reports to its parent base. It is intended to anticipate the possibility of the assignment of the opponent during the submarine will carry out anti-shipping operations, reconnaissance, missile attacks on ground targets and others.

h. Installation / Deployment mines anti-submarine (may include anchor mines, mines base or Captor / encapsulated torpedo) in the waters are quite deep and anti-landing mines in places that allow submarine infiltration / sabotage and others (eg : at the mouth of the bay and the Gulf Balohan Sabang, about Rondo Island).

i. Extension of the Maritime Society is in We Island, and surrounding areas to defend the country and the introduction of awareness and general provisioning against actions and reporting systems to do when encounter a foreign submarine around Bodies We Island, thus the possibility of clandestine operations by submarine opponents can be defeated.

Such efforts as well as patterns of Defense Anti-Submarine in We Island and the surrounding waters, which generally is preventing the enemy submarine using the fundamental function effectively.

\section{Analysis}

We island is an island that has strategic value, which attracted the attention of the aggressor to make the island as a base for sea or air force. This is possible because of its strategic location because it is right at the entrance or exit of the Strait of Malacca and the Indian Ocean. Besides the existing facilities on the island We are also a consideration which strengthens the strategic value of the island. Therefore, it is possible if the war in the Litoral region expands, there will be a certain country concerned to dominate the island.

The waters around We Island, Breueh Island and Rondo Island is enough water in the water which is very well suited for the operation of the submarine, where the submarine is an appropriate means in an effort to paralyze the activities of the defense forces or in a certain area crate We Island.

Some facilities and potential maritime already exist on the We island are all factors favorable to the creation of a defense that is reliable in the face of possible threats to the submarine, but other than that there are Puala some things that are less favorable as the location of We Island are open from all directions sea so that the submarine can be approached from all directions as well. Besides the attractions of the island that invites the presence of many foreign tourists may be the reason the parties intend to dominate the island in intelligence 
gathering for the benefit of the opponents.

By far the factors that are less profitable and increase the favorable factors, it can be formed a strong AntiSubmarine defense system on the island. By increasing the quality and quantity of defense pattern AntiSubmarine, it will create a defense Anti-Submarine is expected to face the threat of these directions that allow the arrival of submarine opponent, while taking into account the ability of the submarine potential adversaries potential, such as the development of the forces Fleet submarines India for example.

\section{Conclusion}

a. Defense Anti-Submarine ideal pattern in We Island are with the utilization of all facilities and the potential to confront any possible threat submarine presence of opponents, and the use of combat function effectively by the opponent, in the waters of We Island and surrounding areas. By estimating the pattern of operation of the submarine opponent, it can be calculated acts of resistance or prevention. The pattern Defense Anti Submarine ideal ship is as follows:

1) Determine the field operations, in this case carry out measurements Bathythermal, levels of salinity and the influence of the depth / pressure and the condition of the hydrographic underwater (background and ambient noise environments, as well as relief and contour / type of seabed) periodically / regularly so that it can be estimated ability sonar operations in the area at any time. It will be closely linked to the use of sensor-sensor tactic to detect submarines.

2) Conduct routine patrols Anti-Submarine either by surface elements, elements of the submarine itself and the air around the element of water which allows or known previously been entered by submarine opponent. Carried out a routine patrol within and outside the catching sector transducer / hydrophones mounted fixed under the sea. Patrol and search for a contact that has been detected previously by fixed hydrophones (in the sector), carried out by road or short distance method (closed area and lost contact search engines to the datum.

3) Installation of hydrophones / transducer (underwater Fixed detecting devices) sepert sosus (can cooperate between LABINBAIR with BPPT), the Strait, a funnel closers, the operation of the submarine areas prone opponent.

4) Installation of Net Anti Submarine / prevent frogmen opponent launched by submarines.

5) Installation of listening devices and Radio Wave Electro Magnetic (ESM and RDF / Huff Duff) at the coast station / land.

6) Placement of posts reviewing the plateau, which is equipped with communication equipment and weapons Cannon Beach to the sea area.

7) Provide education about awareness to defend the country and the introduction of submarine operations to the maritime community in We Island, to prevent / anticipate clandestine operations by submarines.

8) Install Anti Submarine mines deep water to target opponents diving submarine and anti-infiltration mines around / mouth of the bay vital objects.

9) Anti-Submarine Defense Command and Control under the Indonesia Navy Base Commander in Sabang. The elements on the water, under the water and air are under the command of the Base Commander, and is directly responsible to the Commander First Main Naval Base Belawan and Commander First Fleet Command. It was also necessary Commander Sabang naval base need to improve coordination with the Commander Satrad (Unit Radar) Sabang as Command Chief Side and local communities to optimize the ability Maritime Defense base.

10) The elements in the field patrol operations when getting in contact unknown submarine automatically as Commander Battle Action Mandala (Scene of Action Commander) and should be immediately reported to the commander of Sabang naval base any development of the situation until reinforcements arrive.

11). The pattern of attacks against submarine contacts that were classified Possub High 4, Probsub, and Certsub implemented with appropriate attack threat condition situation.

(A) Urgent Attack.

(B) Deliberate Attack.

(C) Stand-off Attack.

(D) Vectac: Radar Vectac, Visual Vectac, Hovertac, Info Tac and Selftac by elements of the air

(E) The pattern of attack, as the red plan (Plan Red).

b. Required some modifications to some of the equipment existing sensors and weapons on warships AntiSubmarine Indonesia Navy, fixed-wing aircraft (Marritime Patrol / MPA) and helicopters to carry out its functions Anti-Submarine for patterns surface operation elements, air and the submarine was above can be applied according to existing procedures. Currently the Indonesia Navy air power have not achieved a good Anti-Submarine (without weapons and sensors Anti-Submarine, except visual). 
c. Surface elements Anti-Submarine ideal / suitable for operating and based in Sabang naval base include warships. Parchim class that is designed to perform the functions Anti-Submarine, as well as class FPB (Fast Patrol Boat) Singa Class, but need to be implemented modifications and additions of the sonar sensor (Hull Mounted Sonar, Variable Depth Sonar and towed array sonar) and the type of weaponry AKS has, such as:

- RBU-6000 should be added that the range.

- $\quad$ torpedoes replaced with modern torpedoes like: Sting Ray, Mk mod-46 C to Parchim Class and, SUT mode 3, DM-2A4 for FPB Singa Class.

- Modifications to the VDS sonar sensors and complementary these elements with TAS (towed array sonar).

Material TCM (Launched TCM) Effector TAU.

While the air element Anti-Submarine is an ideal MPA CN-235 is equipped with MAD, sonobuoy, Water Search Radar, Weapon torpedo MK-46 or Sting Ray, and the helicopters like the Bell 412 is also equipped with radar sensors, sonobuoy, Dipping sonar and MK-46 torpedo weapon or Sting Ray.

\section{References}

Buku armada tempur kapal selam, commander jeff tall OBE RN, September 2010

https://putrarawit.wordpress.com/about/

https://id.wikipedia.org/wiki/Kapal_selam\#Kapal_selam_modern

http://rixcoindonesia.blogspot.co.id/2008/12/sejarah-panjang-kapal-selam.html

http://www.republika.co.id/kanal/leisure/senggang 